\title{
Pengaruh Variasi Bobot Bulking Agent Terhadap Waktu Pengomposan Sampah Organik Rumah Makan
}

\author{
Ika Wahyuning Widiarti \\ Teknik Lingkungan, Fakultas Teknologi Mineral \\ Universitas Pembangunan Nasional "Veteran" Yogyakarta \\ email: ika_wah84@yahoo.co.id
}

\begin{abstract}
Abstrak
Volume sampah organik yang cukup besar selalu dihasilkan dari usaha rumah makan. Untuk mengatasi timbulan sampah organik ini maka upaya yang dapat dilakukan adalah pengomposan. Namun karena sampah ini memiliki kadar air tinggi maka diperlukan bulking agent untuk menurunkan kadar air tersebut. Penelitian ini dilakukan untuk mengetahui pengaruh penambahan bulking agent terhadap waktu pengomposan sampah rumah makan. Variasi bobot bulking agent yang ditambahkan ke sampah rumah makan adalah 10\%, 20\% dan 30\%. Hasil penelitian menunjukkan bahawa bulking agent 30\% mempunyai waktu pengomposan yang tercepat yaitu 26 hari, bulking agent 20\% selama 34 hari dan bulking agent 10\% selama 46 hari. Secara umum, kandungan hara dalam kompos yang dihasilkan dari penelitian memenuhi SNI (19-7030-2004).
\end{abstract}

Kata kunci: Sampah rumah makan, bulking agent, kadar air, waktu pengomposan

\section{Pendahuluan}

Sampah selalu timbul pada setiap aktivitas manusia sehari-hari. Pada umumnya dari timbulan sampah yang ada, sampah organik mempunyai volume yang paling besar. Segala kegiatan manusia baik yang profit maupun nonprofit akan selalu menghasilkan sampah. Demikian pula dengan usaha rumah makan yang merupakan salah satu kegiatan profit. Rumah makan akan selalu dijumpai di segala kota baik yang kecil maupun besar. Di Yogyakarta khususnya banyak dijumpai rumah makan atau restoran karena selain sebagai kota pelajar, Yogyakarta juga dikenal sebagai kota wisata terutama wisata kuliner. Sisa dari usaha rumah makan ini salah satunya adalah berupa sampah organik. Berdasarkan observasi lapangan yaitu di rumah makan Bunga Minang di Jalan Kaliurang, Sleman Yogyakarta diketahui bahwa setiap harinya rumah makan ini menghasilkan sampah organik sebanyak kurang lebih satu 8-10 kg/hari yang terdiri dari sampah organik seperti sisa nasi, sayur, daging dan tulang. Untuk mengatasi timbulan sampah organik yang besar ini maka perlu dilakukan upaya untuk mendaur ulang sampah organik salah satunya dengan mengubahnya menjadi pupuk atau kompos.

Kompos merupakan hasil fermentasi atau hasil dekomposisi bahan organik seperti tanaman, hewan, atau limbah organik. Kompos disebut juga pupuk alami, karena terbuat dari bahan-bahan organik yang ramah lingkungan. Kompos terutama digunakan untuk memperbaiki struktur tanah dan meningkatkan bahan organik tanah. 
Sampah rumah makan yaitu dari sisa makanan dan dapur mempunyai sifat yang unik sebagai bahan mentah kompos, karena sampah ini memiliki kelembaban yang tinggi dan struktur fisik yang rendah. Menurut Simamora dan Salundik (2006), kelembaban yang tinggi (kelebihan air) menyebabkan proses pertukaran udara dalam campuran bahan kompos akan terganggu. Pori-pori udara yang ada dalam tumpukan bahan kompos akan diisi oleh air dan cenderung menimbulkan kondisi anaerobik. Selanjutnya menurut Simamora dan Salundik (2006), bila terjadi kelebihan air maka dapat dilakukan penambahan tanah sebanyak 5-10\% ke dalam campuran bahan baku kompos. Fungsi tanah ini adalah mengatur kelembaban dengan menyerap kelebihan air dalam bahan kompos yang basah yang dikenal sebagai bulking agent. Ada beberapa contoh bulking agent seperti serbuk gergaji, dedaunan kering, jerami dan kompos. Dari beberapa bulking agent tersebut yang memiliki kelebihan adalah kompos dan tanah. Hal ini dikarenakan kompos atau tanah mengandung mikroba yang dibutuhkan dalam proses pengomposan sehingga dapat sekaligus sebagai biostater. Penelitian ini bertujuan untuk mengetahui pengaruh penambahan bulking agent pada berbagai variasi bobot terhadap waktu pengomposan sampah rumah makan dan mengetahui kualitas kompos yang dihasilkan dari pengomposan sampah rumah makan berdasarkan standar kualitas kompos (SNI 19-7030-2004).

\section{Metodologi}

Penelitian dilakukan selama 3 bulan, dimulai dari bulan Desember 2009 hingga Februari 2010. Penelitian dilakukan di Lokasi Daur Ulang Sampah Tambak Boyo, Kab. Sleman, Propinsi Daerah Istimewa Yogyakarta. Analisis bahan baku dan produk kompos dilakukan di Laboratorium Chemmix, Jampidan, Kab. Bantul.

Bahan penelitian yang digunakan meliputi: sampah organik antara lain sisa nasi dan sayur yang merupakan limbah dari beberapa rumah makan Padang dalam wilayah Sleman, Yogyakarta; kompos sebagai bulking agent, kompos yang digunakan adalah "Fine Compost” produksi Lembah Hijau Multifarm, Solo; dan Bioaktivator EM4.

Tabel 1. Komposisi Sampel Penelitian

\begin{tabular}{|c|c|c|c|c|}
\hline No. & $\begin{array}{c}\text { Variasi Bobot Bulking } \\
\text { Agent (\%) }\end{array}$ & $\begin{array}{c}\text { Variasi Bobot Bulking } \\
\text { Agent }(\mathrm{kg})\end{array}$ & $\begin{array}{c}\text { Bobot Sampah } \\
(\mathrm{kg})\end{array}$ & $\begin{array}{c}\text { Bobot Total } \\
(\mathrm{kg})\end{array}$ \\
\hline 1. & $10 \%$ & 0,7 & 7,0 & 7,7 \\
\hline 2. & $20 \%$ & 1,4 & 7,0 & 8,4 \\
\hline 3. & $30 \%$ & 2,1 & 7,0 & 9,1 \\
\hline
\end{tabular}




\section{Hasil dan Pembahasan}

\section{Karakteristik Bahan Baku}

Sampah rumah makan padang yang diambil adalah sisa makanan yang terdiri dari nasi, sayur, laukpauk dan tulang serta banyak mengandung minyak dan air. Sampah sampel penelitian dilakukan perlakuan awal (pre-treatment) terlebih dahulu. Sampel dipilah untuk memisahkan sisa nasi dan sayur dari lauk-pauk seperti daging dan tulang termasuk sampah lain yang tidak terurai, seperti sedotan, plastik dan lainnya. Daging dan tulang dapat mengganggu proses pengomposan karena kandungan proteinnya dapat menimbulkan belatung dan bau. Campuran nasi dan sayur yang telah dipisahkan tersebut lalu ditiriskan dan dijemur di bawah sinar matahari selama \pm 60 menit untuk mengurangi kadar minyak dan air.

Sampel perlu dilakukan analisis awal untuk mengetahui karakteristik bahan baku kompos sebelum dilakukan pengomposan. Analisis awal dilakukan pada sampel yang telah mengalami pre-treatment. Karakteristik awal sampel berdasarkan analisis laboratorium tersaji dalam Tabel 2.

Tabel 2. Karakteristik Sampah Rumah Makan Padang

\begin{tabular}{|l|c|}
\hline \multicolumn{1}{|c|}{ Parameter } & Nilai \\
\hline Kadar Air & $74,06 \%$ \\
\hline$p H$ & 4,1 \\
\hline Bahan Organik & $36,69 \%$ \\
\hline C-organik & $18,56 \%$ \\
\hline Nitrogen & $0,73 \%$ \\
\hline C/N rasio & 25,42 \\
\hline
\end{tabular}

Sumber: Hasil analisis laboratorium

Kadar air dalam sampel masih cukup tinggi yaitu sebesar 74,06\% meskipun telah dilakukan penirisan dan penjemuran. Menurut Djuarnani, dkk (2005), kelembaban ideal untuk pengomposan limbah yang basah adalah 50-60\%. Kelembaban berperan penting dalam proses dekomposisi bahan baku kompos karena berhubungan dengan aktivitas mikroba, sehingga untuk memulai pengomposan kelembaban sampel harus diturunkan antara lain dengan cara menambahkan bulking agent.

\section{Penambahan Bulking Agent}

Bulking agent yang digunakan dalam penelitian ini adalah kompos jadi. Kompos tersebut adalah "Fine Compost” yang diproduksi oleh Lembah Hijau Multifarm, Solo. Bulking Agent dalam penelitian ini hanya berperan mengatur kelembaban sampel dan memberikan porositas terhadap bahan baku. Sedangkan peran lainnya yaitu untuk meningkatkan kandungan energi pada campuran 
bahan, tidak terjadi. Hal ini dikarenakan "Fine Compost” tidak memiliki kandungan karbon organik yang memadai dibandingkan bulking agent lain seperti serbuk gergaji, sekam padi atau dedak. Namun, kelebihan "Fine Compost” sebagai bulking agent adalah dapat berfungsi sebagai inokulum. Namun, pemberian bioaktivator EM4 pada sampel tetap dilakukan.

Penambahan bulking agent ("Fine Compost”) awalnya menggunakan variasi 5\%, 7,5\% dan 10\%. Namun, untuk kasus sampah rumah makan ini penambahan 5-10\% bulking agent belum dapat menurunkan kelembaban bahan baku secara berarti. Kadar air yang diperoleh setelah penambahan bulking agent dengan variasi ini masih berada di atas 70\%. Hal ini dapat dilihat pada Tabel 3 yang memberikan karakteristik bahan baku hari ke-0 untuk penambahan bulking agent 5\%, 7,5\% dan 10\%. Oleh karena itu, variasi penambahan bulking agent diubah menjadi 10\%, 20\% dan 30\%.

Tabel 3. Kadar Air, pH, Nitrogen, dan Karbon Bahan Baku Hari ke-0 untuk Bulking Agent 5\%, 7,5\% dan 10\%.

\begin{tabular}{|l|r|r|r|r|}
\hline \multicolumn{1}{|c|}{ Parameter } & Awal & BA 5\% & BA 7,5\% & BA 10\% \\
\hline Kadar Air (\%) & 77,67 & 75,08 & 74,26 & 73,72 \\
\hline pH & 4,1 & 4 & 4,1 & 4,2 \\
\hline Nitrogen (\%) & 0,52 & 0,45 & 0,12 & 0,06 \\
\hline C-organik (\%) & 10,40 & 12,55 & 12,76 & 13,05 \\
\hline
\end{tabular}

Sumber: Hasil analisis laboratorium

Penambahan bulking agent dengan variasi 10\%, 20\%, dan 30\% ke dalam sampel yang telah mengalami pre-treatment ternyata mengurangi kadar air lebih tinggi dibandingkan dengan penambahan bulking agent dengan variasi 5\%, 7,5\%, dan 10\%. Karakteristik dari penambahan bulking agent dengan variasi 10\%, 20\%, dan 30\% ditunjukkan dalam Tabel 4.

Tabel 4. Kadar Air, pH, Nitrogen, dan Karbon Bahan Baku Hari ke-0 untuk Bulking Agent 10\%, 20\% dan 30\%

\begin{tabular}{|l|l|l|l|l|}
\hline \multicolumn{1}{|c|}{ Parameter } & \multicolumn{1}{|c|}{ Awal } & \multicolumn{1}{c|}{ BA 10\% } & \multicolumn{1}{c|}{ BA 20\% } & \multicolumn{1}{c|}{ BA 30\% } \\
\hline Kadar Air (\%) & 74,06 & 67,16 & 67,15 & 62,75 \\
\hline pH & 4,1 & 4,3 & 4,4 & 4,7 \\
\hline Nitrogen (\%) & 0,73 & 0,64 & 0,90 & 0,75 \\
\hline C-organik (\%) & 18,56 & 15,70 & 15,11 & 16,76 \\
\hline C-organik pada basis kadar air 15\%* & 60,83 & 40,64 & 39,09 & 38,25 \\
\hline
\end{tabular}

catatan: *Hasil perhitungan

Sumber: Hasil analisis laboratorium

Perbedaan perlakuan awal menyebabkan adanya perbedaan kadar air yang ada pada sampel. Perbedaan tersebut dapat dilihat dari Tabel 3 dan 4 untuk kondisi awal sampel sebelum pengomposan. Pada penggunaan bulking agent 5\%, 7,5\% dan 10\%, kadar air sampah sebesar 77,67\%. Sedangkan ketika dilakukan pre-treatment untuk penggunaan bulking agent 10\%, 20\% dan 30\% menyebabkan kadar air sampah turun hingga menjadi 74,06\%. 
Tabel 3 menunjukkan bahwa penambahan bulking agent dengan variasi 5\%, 7,5\% dan 10\% pada sampah tidak memberikan penurunan yang berarti. Hal ini dapat ditunjukkan dengan persentase perbandingan kondisi awal dengan kondisi setelah ditambahkan bulking agent seperti yang terlihat di Tabel 5. Sedangkan untuk penambahan bulking agent dengan variasi 10\%, 20\% dan 30\% memberikan penurunan kadar air lebih besar dibandingkan dengan variasi 5\%, 7,5\% dan 10\%. Hal ini dapat dilihat pada Tabel 5.

Tabel 5. Perbandingan Kondisi Awal Bahan dengan Kondisi setelah Ditambahkan Bulking Agent 5\%, 7,5\% dan 10\%

\begin{tabular}{|l|c|c|c|}
\hline \multicolumn{1}{|c|}{ Parameter } & BA 5\% & $B A 7,5 \%$ & $B A 10 \%$ \\
\hline Penurunan Kadar Air & $3,33 \%$ & $4,39 \%$ & $5,09 \%$ \\
Kenaikan pH & $2,44 \% *$ & $0,00 \%$ & $2,44 \%$ \\
\hline
\end{tabular}

Catatan: *terjadi penurunan $\mathrm{pH}$

Sumber: Hasil perhitungan

Tabel 6. Perbandingan Kondisi Awal Bahan dengan Kondisi setelah Ditambahkan Bulking Agent 10\%, 20\% dan 30\%

\begin{tabular}{|l|r|c|c|}
\hline \multicolumn{1}{|c|}{ Parameter } & BA 10\% & BA 20\% & BA 30\% \\
\hline Penurunan Kadar Air & $9,32 \%$ & $9,33 \%$ & $15,27 \%$ \\
Kenaikan pH & $4,88 \%$ & $7,32 \%$ & $14,63 \%$ \\
\hline
\end{tabular}

Sumber: Hasil perhitungan

\section{Pengomposan}

\section{a. Perubahan Suhu}

Selama proses pengomposan dilakukan pengukuran suhu setiap hari untuk melihat jalannya proses pengomposan. Pengukuran suhu dilakukan pada pagi hari dan pengadukan dilakukan pada sore hari. Pengadukan ini bertujuan untuk meningkatkan aerasi dalam tumpukan bahan baku karena karakter bahan baku yang sangat basah dapat menyebabkan penetrasi oksigen ke dalam tumpukan menjadi terhambat.

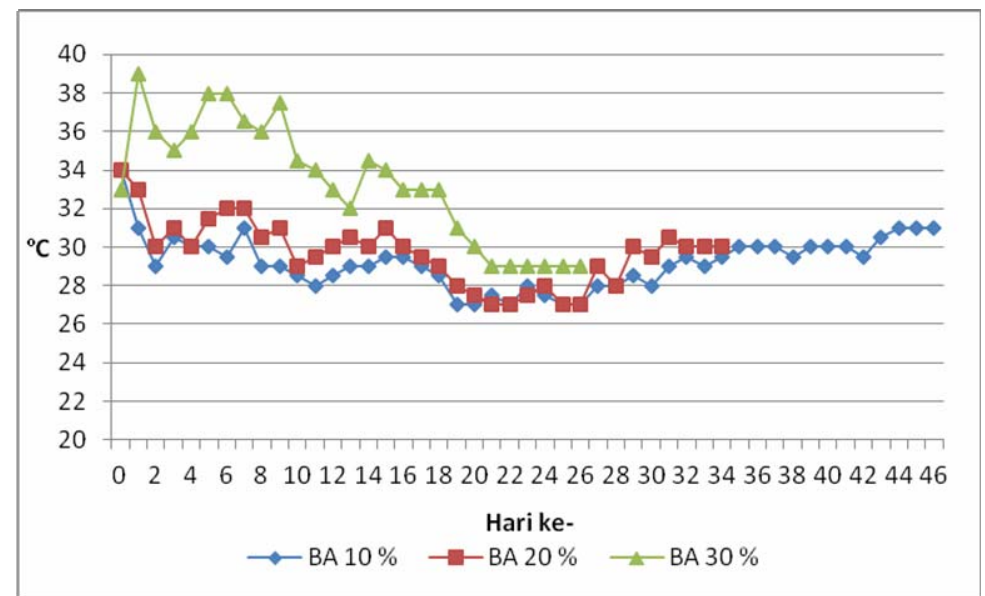

Gambar 1. Hasil Pengukuran Suhu pada Tumpukan Kompos 
Gambar 1 memperlihatkan bahwa peningkatan suhu di awal pengomposan dan penurunan suhu di akhir proses hanya terjadi pada bulking agent 30\%. Suhu pada bulking agent 30\% mengalami peningkatan yang paling tinggi diantara yang lain. Suhu optimum dicapai pada hari ke-1 yaitu $39^{\circ} \mathrm{C}$. Dan kemudian berfluktuasi hingga mencapai stabil pada suhu $29^{\circ} \mathrm{C}$ di akhir proses pengomposan yaitu pada hari ke-26. Hal ini menandakan bahwa pengomposan berjalan dengan cukup baik. Menurut Hartutik, dkk (2009) kenaikan suhu di awal pengomposan terjadi karena adanya aktivitas mikroba dalam mendekomposisi bahan organik dengan oksigen sehingga menghasilkan energi dalam bentuk panas, $\mathrm{CO}_{2}$, dan uap air. Panas yang ditimbulkan akan tersimpan dalam tumpukan, sementara di bagian permukaan terpakai untuk penguapan. Panas yang terperangkap dalam tumpukan akan menaikkan suhu tumpukan. Setelah mencapai suhu puncak, suhu tumpukan mengalami penurunan yang akan stabil sampai proses pengomposan berakhir.

Proses pengomposan pada bulking agent 10\% dan 20\% tidak berjalan dengan baik. Hal ini dapat dilihat pada perubahan suhu yang terjadi selama proses pengomposan. Suhu optimum yang dapat dicapai pada bulking agent $10 \%$ hanya $34^{\circ} \mathrm{C}$ pada hari ke-0. Selanjutnya suhu berfluktuasi hingga pada akhir pengomposan terjadi kestabilan suhu yaitu $31^{\circ} \mathrm{C}$ pada hari ke-46. Perubahan suhu yang tidak sesuai ini kemungkinan disebabkan oleh tumpukan bahan baku yang terlalu basah sehingga oksigen tidak dapat masuk ke dalam tumpukan sampah dan terjadi proses pengomposan secara anaerobik. Proses pengomposan secara anaerobik menurut Djuarnani, dkk (2005) merupakan proses dingin dan tidak terjadi fluktuasi suhu seperti yang terjadi pada proses pengomposan secara aerobik. Begitu pula pada penambahan bulking agent 20\%, perubahan suhu terjadi secara fluktuatif dengan suhu tertinggi $34^{\circ} \mathrm{C}$. Suhu cenderung menurun dari awal hingga akhir pengomposan. Suhu menjadi stabil di akhir proses pengomposan yaitu $30^{\circ} \mathrm{C}$ pada hari ke-34. Dapat disimpulkan bahwa penambahan bulking agent $10 \%$ dan $20 \%$ belum dapat memberikan kondisi yang ideal untuk pengomposan sampah rumah makan karena tumpukan bahan baku masih kelebihan air sehingga menyebabkan proses pengomposan menjadi anaerobik.

Berdasarkan suhu yang teramati, proses pengomposan hanya berjalan pada suhu mesofilik yaitu di bawah $45^{\circ} \mathrm{C}$. Proses pengomposan yang baik, menurut Salundik dan Simamora (2007) pada awal dekomposisi mikroorganisme yang terlibat dalam proses pengomposan adalah jenis mesofilik. Beberapa hari setelah terfermentasi, suhu pengomposan meningkat sehingga peran mikroorganisme mesofilik digantikan mikroorganisme termofilik (di atas $65^{\circ} \mathrm{C}$ ). Setelah suhu pengomposan turun lagi, mikroorganisme mesofilik akan aktif kembali. Suhu yang tinggi berperan untuk membunuh mikroorganisme patogen. Karena tidak tercapai suhu termofilik, maka dimungkinkan kompos yang dihasilkan dalam penelitian ini masih mengandung mikroba patogen. 


\section{b. Perubahan Derajat Keasaman}

Awal proses pengomposan sampah rumah makan bersifat asam dengan $\mathrm{pH}$ berkisar di bawah 5 . Selama proses pengomposan tidak terjadi penurunan $\mathrm{pH}$, tetapi dari awal hingga akhir pengomposan $\mathrm{pH}$ cenderung naik mendekati netral. Perubahan $\mathrm{pH}$ yang teramati dalam penelitian ini disajikan dalam Gambar 2.

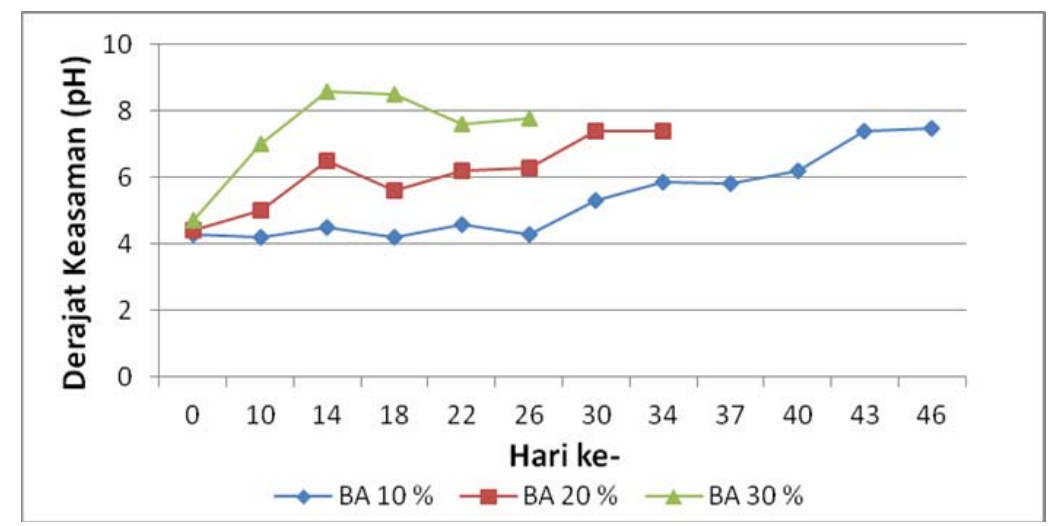

Gambar 2. Perubahan $\mathrm{pH}$ pada Tumpukan Kompos

Terlihat pada Gambar 2, pH pada bulking agent 30\% terjadi kenaikan pH yang cukup tinggi dibandingkan dengan 20\% dan 10\%. Menurut Polpraset dalam Zaman dan Sutrisno (2007), proses yang terjadi adalah pada awal pengomposan terjadi dekomposisi bahan-bahan organik yang kompleks dan bersifat reaktif seperti gula, tepung, karbohidrat, lemak menjadi asam organik sederhana. Setelah itu akan terjadi kenaikan pH sehingga keadaan berubah menjadi basa. Hal ini disebabkan asam-asam organik sederhana yang terbentuk pada dekomposisi awal tadi dikonversi menjadi metana, amoniak dan $\mathrm{CO}_{2}$ oleh bakteri pembentuk metan. Setelah mengalami kenaikan $\mathrm{pH}$ pada titik tertinggi yaitu 8,6 tumpukan kompos mengalami penurunan $\mathrm{pH}$ atau tahap pendinginan. Pada tahap ini terjadi proses peruraian bahan resisten seperti lignin, hemiselulosa dan selulosa oleh Fungi dan Actinomycetes sehingga pH menunjukkan kestabilan mendekati netral yaitu sekitar 7,8 (Zaman dan Sutrisno, 2007).

Proses peningkatan $\mathrm{pH}$ yang cenderung naik secara bertahap juga terjadi pada penambahan bulking agent $10 \%$ dan $20 \%$. Pada bulking agent 10\% terjadi kenaikan $\mathrm{pH}$ yang lebih lambat dibandingkan dengan penambahan bulking agent 20\%. Hal ini disebabkan karena proses yang terjadi dalam tumpukan kompos bulking agent 10\% adalah fakultatif anaerob. Pada proses ini, ada dua jenis mikroba yang bekerja dalam proses dekomposisi. Ketika kondisi terdapat oksigen (dilakukan pengadukan) mikroba aerob akan bekerja, tetapi ketika oksigen habis secara spontan mikroba anaerob akan bekerja. Proses dekomposisi anaerob memerlukan waktu yang lebih lama daripada aerob. 
Proses dekomposisi sampah dengan bulking agent 20\% berlangsung lebih cepat daripada bulking agent $10 \%$ walaupun tidak secepat dekomposisi pada bulking agent $30 \%$. Hal ini dapat terlihat pada perubahan $\mathrm{pH}$ yang tersaji pada Gambar 2. Berdasarkan perubahan $\mathrm{pH}$ yang ditunjukkan dalam Gambar 2 dapat disimpulkan bahwa penambahan bulking agent 30\% menyebabkan proses pengomposan berjalan paling baik dibandingkan dengan bulking agent $10 \%$ dan $20 \%$. Proses pengomposan pada bulking agent 20\% berjalan lebih baik daripada bulking agent 10\%. Pada bulking agent $10 \%$ terjadi proses pengomposan fakultatif anaerobik sehingga proses pengomposan berjalan lambat.

\section{c. Perubahan Kandungan Karbon Organik}

Analisis perubahan kandungan karbon dilakukan untuk melihat terjadinya dekomposisi bahan organik oleh mikroba selama proses pengomposan. Dalam proses pengomposan karbon organik dalam bahan baku kompos akan digunakan mikroba sebagai sumber energi dan pembentuk sel (Djuarnani dkk, 2005). Selama proses pengomposan terjadi perubahan bahan organik menjadi senyawa baru oleh mikroba dengan persamaan reaksi (5) sebagai berikut:

$$
\text { Bahan organik }+\mathrm{O}_{2}+\text { nut } \underset{\text { mikroba }}{\longrightarrow} \text { bahan organik stabil }+\mathrm{CO}_{2}+\mathrm{H}_{2} \mathrm{O}+\mathbf{N H}_{3}+\mathrm{Kalor}^{\uparrow}
$$

Persamaan (5) merupakan fungsi waktu, suhu dan kadar air. Persamaan (5) menjelaskan bahwa semakin lama waktu berjalan, proses dekomposisi bahan organik semakin meningkat. Selama berjalannya waktu terjadi penurunan jumlah bahan organik dan konsumsi oksigen. Seiring dengan penurunan bahan organik dalam sampah terjadi pula peningkatan jumlah bahan organik stabil, $\mathrm{CO}_{2}$ dan $\mathrm{NH}_{3}$ yang dibebaskan. Bahan organik stabil dalam hal ini adalah humus dan unsur hara lainnya. Kandungan karbon organik selama proses pengomposan tersaji dalam Tabel 7.

Tabel 7. Persen Karbon Organik Hasil Pengomposan (Basis Kadar Air 15\%)

\begin{tabular}{|c|c|c|c|}
\hline Hari ke- & BA 10\% & BA 20\% & BA 30\% \\
\hline 0 & 40,63756 & 39,08537 & 38,24704 \\
\hline 18 & 35,81677 & 36,76174 & 30,31421 \\
\hline 22 & 36,28326 & 32,07665 & 30,25651 \\
\hline 26 & 35,73319 & 32,30327 & 30,08896 \\
\hline 30 & - & 34,67375 & \\
\hline 34 & - & 18,23757 & \\
\hline 37 & 34,27184 & & \\
\hline 40 & - & & \\
\hline 43 & 32,73004 & & \\
\hline 46 & 25,24701 & & \\
\hline
\end{tabular}

Sumber: Hasil perhitungan dari hasil analisis laboratorium dengan basis kadar air 15\% 


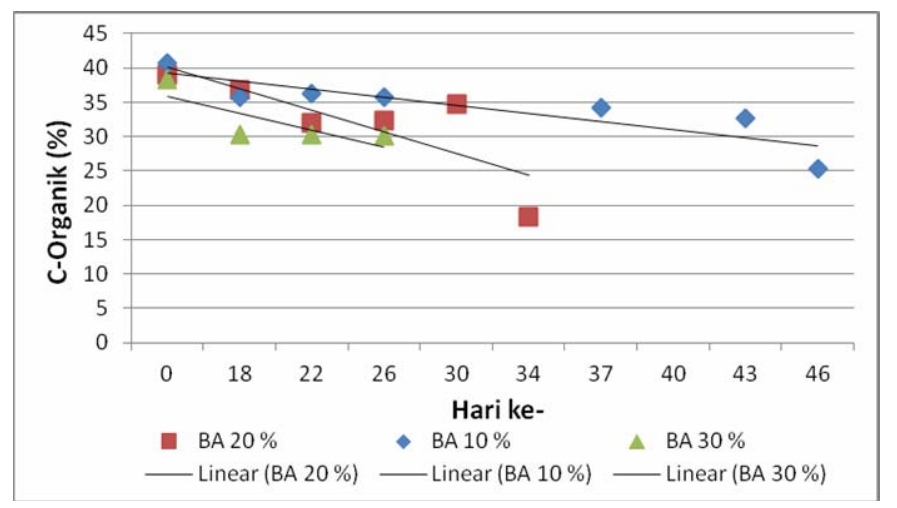

Gambar 3. Kandungan Karbon Organik dalam Tumpukan Kompos

Gambar 3 memperlihatkan terjadinya perubahan kandungan karbon organik pada proses pengomposan sampah rumah makan pada seluruh variasi bulking agent. Analisis pertama dilakukan pada hari ke-18 karena diasumsikan akan terjadi penurunan kandungan karbon organik yang cukup besar. Dari ketiga variasi, penurunan terbesar terjadi pada penambahan bulking agent 30\%. Hal ini dikarenakan proses dekomposisi yang berlangsung dengan cepat ditandai dengan tingginya suhu pengomposan sehingga terjadi konsumsi karbon organik yang besar oleh mikroba. Selanjutnya, pada hari berikutnya penurunan karbon organik pada bulking agent 30\% mengalami penurunan yang tidak terlalu besar. Setelah pH mencapai netral pada hari ke-26, proses pengomposan dihentikan dan diperoleh kandungan karbon organik sebesar 30,08896\%.

Kandungan karbon organik pada penambahan bulking agent 20\% pada hari ke-18 lebih rendah dibandingkan dengan bulking agent 30\%. Kemudian pada hari ke-22 terjadi penurunan karbon organik menjadi 32,07665\%. Namun, pada hari ke-26 dan 30 terjadi peningkatan kandungan karbon organik. Hal ini dimungkinkan terjadi kontaminasi sampel ketika dilakukan analisis kandungan karbon dalam laboratorium. Selanjutnya pada akhir pengomposan ( $\mathrm{pH}$ sudah mendekati netral) yaitu hari ke-34, terjadi penurunan karbon organik yang cukup drastis yaitu menjadi 18,23757\%.

Penurunan kandungan karbon organik pada bulking agent 10\% pada hari ke-18 hampir sama seperti pada bulking agent 20\%. Dari hari ke-22 hingga hari ke-43 penurunan karbon organik sangat lambat. Penurunan karbon organik yang lambat ini dipengaruhi oleh proses pengomposan yang berjalan secara fakultatif anaerob. Kemudian karbon organik menurun hingga 25,24701\% pada akhir pengomposan yaitu pada hari ke-46.

\section{Kompos Matang}

Kematangan kompos dalam penelitian ini ditandai dengan melihat penampakan fisiknya meliputi warna dan bau serta perubahan suhu dan $\mathrm{pH}$. Warna kompos yang sudah matang adalah semakin coklat kehitaman, bau sampah telah berubah menjadi bau seperti tanah, suhu kompos mendekati suhu tanah sekitar 26-30 ${ }^{\circ} \mathrm{C}$ dan $\mathrm{pH}$ kompos di sekitar 7. 
Ketiga variasi, bulking agent 30\% mengalami pematangan kompos yang paling cepat dari yang lainnya yaitu 26 hari. Sedangkan kompos untuk bulking agent 20\% matang pada hari ke-34 dan kompos untuk bulking agent 10\% matang pada hari ke-46. Pada Tabel 8 menunjukkan parameter fisik kompos yang matang dari ketiga variasi.

Tabel 8. Kompos Matang Sebelum dan Sesudah Pengeringan

\begin{tabular}{|l|l|l|l|l|l|l|}
\hline \multirow{2}{*}{ Parameter } & \multicolumn{3}{|c|}{ Sebelum Pengeringan } & \multicolumn{3}{c|}{ Sesudah Pengeringan } \\
\cline { 2 - 7 } & BA 10\% & BA 20\% & BA 30\% & BA 10\% & BA 20\% & BA 30\% \\
\hline Bau & $\begin{array}{l}\text { Masih bau } \\
\text { sampah }\end{array}$ & Bau tanah & Bau tanah & Bau tanah & Bau tanah & Bau tanah \\
\hline Warna & Abu-abu & $\begin{array}{l}\text { Coklat } \\
\text { muda }\end{array}$ & $\begin{array}{l}\text { Coklat } \\
\text { hitam }\end{array}$ & $\begin{array}{l}\text { Abu } \\
\text { kecoklatan }\end{array}$ & Coklat tua & $\begin{array}{l}\text { Coklat } \\
\text { kehitaman }\end{array}$ \\
\hline Suhu & $31^{\circ}$ & $30^{\circ}$ & $29^{\circ}$ & $31^{\circ}$ & $30^{\circ}$ & $29^{\circ}$ \\
\hline pH & 7,5 & 7,4 & 7,8 & 7,5 & 7,4 & 7,8 \\
\hline
\end{tabular}

Sumber: Hasil pengamatan

Tahap berikutnya setelah kompos matang adalah pengeringan. Hal ini dilakukan karena saat kompos sudah matang kadar air kompos masih sangat tinggi. Pengeringan dilakukan di bawah sinar matahari hingga diperoleh kadar air 15\%. Kadar air tidak berpengaruh secara langsung terhadap kualitas kompos, tetapi mempengaruhi penanganan kompos berikutnya seperti penyimpanan dan aplikasi akhir. Kadar air yang terlalu tinggi menyebabkan kompos tidak dapat disimpan lama karena resiko diserang oleh jamur dan cendawan. Jamur dan cendawan ini akan menurunkan kualitas kompos bahkan dapat merubah kompos menjadi beracun (Komarayati dkk, 2007).

Tabel 9. Hasil Uji Kompos Matang dan Bandingannya Terhadap SNI 19-7030-2004

\begin{tabular}{|l|l|l|l|l|l|}
\hline No. & Parameter & BA 10\% & BA 20\% & BA 30\% & Standar SNI \\
\hline 1. & Kadar Air (\%) & 15 & 15 & 15 & Maks 50 \\
\hline 2. & Suhu $\left({ }^{\circ} \mathrm{C}\right)$ & 31 & 30 & 29 & Suhu air tanah (26-30) \\
\hline 3. & Warna & Coklat & Coklat & $\begin{array}{l}\text { Hitam } \\
\text { kecoklatan }\end{array}$ & Kehitaman \\
\hline 4. & Bau & Tanah & Tanah & Tanah & Bau Tanah \\
\hline 5. & pH & 7,5 & 7,4 & 7,8 & $6,8-7,49$ \\
\hline Unsur Makro (Basis Kadar Air 15\% (Pasca Pengeringan)) \\
\hline 6. & Bahan Organik (\%) & 49,4877 & 49,5253 & 58,9453 & $27-58$ \\
\hline 7. & Nitrogen (\%) & 3,3784 & 5,5233 & 4,6479 & Min 0,4 \\
\hline 8. & C-organik(\%) & 25,2470 & 25,2423 & 30,0890 & $9,80-32$ \\
\hline 9. & Rasio C/N & 7,4731 & 4,5701 & 6,4737 & $10-20$ \\
\hline 10. & $\mathrm{P}_{2} \mathrm{O}_{5}(\%)$ & 2,0353 & 0,4413 & 0,7222 & Min 0,1 \\
\hline 11. & $\mathrm{~K}_{2} \mathrm{O}(\%)$ & 1,6497 & 6,1364 & 3,6359 & Min 0,2 \\
\hline
\end{tabular}

Sumber: Hasil analisis laboratorium dan perhitungan. 
Rasio C/N pada ketiga kompos yang terendah adalah kompos dengan bulking agent 20\%, sedangkan yang tertinggi adalah pada kompos dengan bulking agent 10\%. Hal ini menunjukkan bahwa meskipun waktu pengomposan dengan bulking agent 30\% lebih cepat daripada bulking agent $10 \%$, bukan berarti bahwa kualitas kompos dengan bulking agent 30\% lebih baik dari kompos dengan bulking agent 10\%. Kandungan fosfor untuk ketiga variasi bulking agent berada pada nilai 0,4413-2,0353\%, yang berarti kandungan fosfor pada ketiga kompos sesuai dengan SNI yaitu minimal 0,1\%. Kandungan fosfor terbesar adalah pada kompos dengan bulking agent 10\% dan yang terendah adalah kompos dengan bulking agent 20\%. Untuk kandungan kalium pada ketiga variasi bulking agent berada pada nilai 1,6497-3,5359\%, yang berarti kandungan kalium pada ketiga kompos sesuai dengan SNI yaitu lebih dari 0,2\%. Kandungan kalium terbesar adalah pada kompos dengan bulking agent 30\% dan yang terendah adalah kompos dengan bulking agent 10\%.

\section{Kesimpulan dan Saran}

\section{Kesimpulan}

1. Sampah organik rumah makan dapat diubah menjadi pupuk kompos.

2. Penambahan bulking agent yaitu "Fine Compost” pada pengomposan sampah organik rumah makan Padang mempengaruhi waktu pengomposan.

3. Waktu pengomposan tercepat terjadi pada kompos dengan penambahan bulking agent 30\% yaitu 26 hari dan pada bulking agent 20\% yaitu 34 hari. Kandungan karbon organik akhir untuk bulking agent 30\% dan 20\% adalah 30,08896\% dan 18,23757\%.

4. Kandungan hara dalam kompos hasil penelitian pada ketiga variasi bobot secara umum memenuhi standar kualitas SNI 19-7030-2004. Namun, rasio C/N akhir produk tidak memenuhi SNI yaitu lebih kecil dari 10 .

5. Rasio $\mathrm{C} / \mathrm{N}$ kompos untuk bulking agent 10\%, 20\% dan 30\% berturut-turut adalah 7,4731, 4,5701 dan 6,4737.

6. Berdasarkan analisis kandungan hara, penambahan bulking agent pada berbagai bobot tidak mempengaruhi kualitas kompos yang dihasilkan.

\section{Saran}

1. Penirisan dan pengeringan bahan baku yang lebih lama untuk menurunkan kadar air sehingga bulking agent yang ditambahkan kurang dari 30\% dan diharapkan waktu pengomposan kurang dari 26 hari. 
2. Jika menghendaki kompos sebagai bulking agent dalam mengomposkan sampah basah, maka perlu ditambahkan bulking agent lain seperti dedak untuk meningkatkan kandungan karbon.

3. Perlu adanya pengadukan yang lebih merata agar distribusi oksigen dalam tumpukan kompos maksimal.

\section{Daftar Pustaka}

Djuarnani, N., dkk. (2005). Cara Cepat Membuat Kompos. Agromedia Pustaka.

Komarayati, Sri., Mustaghfirin, dan Kurnia Sofyan. (2007). Kualitas Arang Kompos Limbah Industri Kertas dengan Variasi Penambahan Arang Serbuk Gergaji. Jurnal Ilmu \& Teknologi Кауи Tropis Volume 5 Nomor 2. http://www.disnak.jabarprov.go.id/images/ artikel/kompos\%20gergaji.pdf diakses tanggal 13 Januari 2010.

Simamora, S., dan Salundik. (2006). Meningkatkan Kualitas Kompos. Agromedia Pustaka.

Zaman, B., dan E. Sutrisno. (2007). Studi Pengaruh Pencampuran Sampah Domestik, Sekam Padi, dan Ampas Tebu dengan Metode Mac Donald terhadap Kamatangan Kompos. Jurnal Presipitasi, Volume 2 Nomor 1. 